\title{
Durabilidad de granitos ornamentales: valoración de los daños inducidos por el ensayo de cristalización de sales
}

\section{Ornamental granite durability: evaluation of damage caused by salt crystallization test}

\author{
F. J. Alonso(*), P. Vázquez (*), R. M. Esbert(*) y J. Ordaz(*)
}

Recepción/Received: 15-V-07

Aceptación/Accepted: 25-IX-07

Publicado online/Online publishing: 21-XII-07

\section{RESUMEN}

El ensayo de cristalización de sales se utiliza para valorar los daños provocados por las sales solubles que penetran en la roca, cuando éstas cristalizan en sus espacios vacíos (poros o fisuras). En este trabajo se ha valorado el comportamiento de cuatro granitos ornamentales de Galicia (Gris Alba, Grissal, Rosa Porriño y Rosavel) sometidos al ensayo normalizado UNE-EN 12370. Las rocas estudiadas tienen una porosidad abierta inferior al 5\%; por ello, la pérdida de masa es prácticamente inexistente. Sin embargo, algunas propiedades físicas como la velocidad de propagación de ondas, la rugosidad superficial y el color experimentan variaciones a lo largo de los ciclos. Los autores proponen que para evaluar debidamente la durabilidad de este tipo de rocas no sólo debe tenerse en cuenta la pérdida de masa, sino que también deben medirse las propiedades mencionadas, especialmente si los granitos van a ser utilizados para revestimiento de exteriores.

Palabras clave: durabilidad, granito, cristalización de sales, propiedades físicas, rugosidad.

\section{SUMMARY}

The salt crystallization test is used to evaluate damage caused by soluble salts that penetrate stone and subsequently crystallize in its voids (pores or cracks). The present article discusses the behaviour for four ornamental granites (Gris Alba, Grissal, Rosa Porriño and Rosavel) tested to European and Spanish standard UNE-EN 12370. Since the rocks studied had an open porosity of under $5 \%$, their weight loss was practically nil. Nonetheless, certain physical properties such as wave propagation, surface roughness and colour were found to vary after testing. The authors feel that durability in such stones should be based not on weight loss alone, but on the other properties mentioned as well, particularly in the case of granite that is to be used for cladding in exteriors.

Keywords: durability, granite, salt crystallization, phisical properties, roughness.

(*) Universidad de Oviedo. (Oviedo, España). 


\section{INTRODUCCIÓN}

El uso de piedra natural como material de edificación, principalmente en fachadas y paramentos exteriores, ha aumentado considerablemente en los últimos años. Este hecho ha acrecentado la importancia de que las rocas ornamentales, una vez colocadas en el edificio, mantengan las propiedades -tanto físicas como estéticas- que les dan valor. Para conocer la evolución de dichas propiedades frente a agentes agresivos, entre los que destacan por su importancia las sales solubles, es preciso realizar ensayos de durabilidad. Es sabido que las sales solubles ocasionan daños físicos y químicos en las piedras cuando cristalizan en su interior o en su superficie (1-3); ejemplos de estos daños, los podemos encontrar en numerosos edificios, algunos construidos con granito como la catedral de Santiago de Compostela o la Torre de Moncorvo en Portugal (4).

Para valorar la acción de las sales solubles las rocas se someten al ensayo de cristalización de sales. La norma UNE-EN 12370 relativa a la piedra natural (5), indica que el ensayo debe realizarse en materiales con una porosidad mayor del 5\%, de modo que las sales puedan albergarse fácilmente en su interior y causar daños manifiestos. Sin embargo, este ensayo también tiene interés en granitos con porosidad inferior al $5 \%$, ya que las sales, según se ha constatado experimentalmente, suelen producir efectos nocivos que se traducen en la creación de fisuras o apertura de las ya existentes. Si estas rocas se usan como losetas de revestimiento es crucial evaluar los daños generados por las sales en su superficie.

El objetivo de este estudio es valorar los cambios producidos en granitos utilizados como piedra de revestimiento, cuando se someten a ensayos de cristalización de sales. Dichos cambios permiten estimar el deterioro de estas rocas cristalinas de baja porosidad y predecir su comportamiento una vez puestas en obra. Como criterios de valoración se han tenido en cuenta las variaciones experimentadas por determinadas características y propiedades, tales como: masa de las probetas, velocidad de propagación de ondas longitudinales, rugosidad superficial y color.

La pérdida de masa es uno de los efectos más importantes que produce la cristalización de sales, y el único criterio cuantitativo que recoge la norma. La cristalización de las sales provoca saltación de granos y descohesión (6); en granitos poco alterados y para un corto número de ciclos (15, como indica la norma) la pérdida de masa es poco significativa.

Al cristalizar las sales en el interior de las fisuras modifican el sistema microfisural de las rocas (7). Dada la relación existente entre el grado de fisuración y la velocidad

\section{INTRODUCTION}

The use of natural stone as a building material, particularly on facades and exterior surfaces, has increased considerably in recent years. This has made it more important for ornamental stone to maintain both the physical and aesthetic properties for which it is valued. Variations in these properties when stone is exposed to aggressive agents, of which soluble salts are the most prominent, can be ascertained with durability tests. Soluble salts are known to cause physical and chemical damage when they crystallize on stone surfaces or interiors (1-3); examples of such damage may be found in any number of buildings, including granite monuments such as Santiago de Compostela Cathedral or Moncorvo Tower in Portugal (4).

Rocks are subjected to salt crystallization tests to evaluate their resistance to soluble salts. Spanish and European standard UNE-EN 12370 on natural stone (5) specifies that the test should be conducted on materials with a porosity of over 5\%, which are readily penetrated and visibly damaged by salts. This test is also useful for granite with a porosity of under 5\%, however, for experiments have shown that in these cases also salt may cause adverse effects that translate into the appearance of new or the widening of existing cracks. Evaluation of the surface damage induced by salt is crucial particularly for stone to be used as cladding.

The present study aimed to evaluate the changes occurring in granite for cladding when subjected to salt crystallization tests. Low porosity rock deterioration and its performance after placement can be estimated from such changes. The evaluation criteria used were variations in characteristics and properties such as: specimen mass, longitudinal wave propagation velocity, surface roughness and colour.

The loss of mass is one of the most important effects caused by salt crystallization and the only quantitative criterion laid down in the standard. Although salt crystaIlization causes spalling and crumbling (6), in scantly altered granite subjected to a small number of cycles $(15$, as specified in the standard), mass loss is barely significant.

When salts crystallize inside cracks they change the microcrack structure (7). Given the relationship between degree of cracking and wave propagation velocity $(8,9)$, 
de propagación de ondas $(8,9)$, puede utilizarse este parámetro para cuantificar los cambios producidos en la red fractográfica por el efecto de la sal.

En los granitos pulidos es importante que el pulimento se mantenga el mayor tiempo posible tras su exposición a la intemperie. Las sales solubles también producen daños que afectan al pulido debido principalmente a la creación y apertura de fisuras, así como a la exfoliación y rotura de micas. Estos daños pueden ser cuantificados mediante la medida de la rugosidad.

El color es otra propiedad importante en las rocas ornamentales. La cristalización de sales puede dar lugar a cambios de color en la superficie de la piedra, incluso después de ser eliminadas. Dichos cambios de color pueden estar relacionados con variaciones de rugosidad, tal como se ha observado en otras litologías (10).

\section{GRANITOS SELECCIONADOS}

Se han elegido cuatro granitos ornamentales de Galicia (NW de España), correspondientes a las denominaciones comerciales: Gris Alba, Grissal, Rosa Porriño y Rosavel (Figura 1). Todas ellas son rocas sanas, con menos del $5 \%$ de espacios vacíos (fisuras), aunque presentan ciertas diferencias en su mineralogía, color y tamaño de grano (Tabla 1). En trabajos previos (11) se han analizado las propiedades hídricas de algunos de estos granitos (Rosa Porriño y Rosavel) con distintos acabados superficiales.

Gris Alba es un monzogranito de color gris, equigranular, de grano medio; es la roca más fisurada, con una apertura de fisuras alrededor de $8 \mu \mathrm{m}$. Grissal también es un monzogranito de color gris, en este caso heterogranular de grano grueso; es la roca menos fisurada y de menor this parameter can be used to quantify changes taking place in the crack network as a result of salt attack.

In polished granite, the finish must be maintained for as long as possible after exposure to the elements. Soluble salts also cause damage that affect polishing, due primarily to the appearance and widening of cracks and mica flaking and cleavage. This type of damage can be quantified by measuring roughness.

Colour is another important property of ornamental rocks. Salt crystallization may give rise to colour changes on the stone surface, even after the crystals are washed away. Such changes may be related to variations in roughness, as observed in other lithologies (10).

\section{GRANITE SELECTED}

Four ornamental granites from Galicia (NW Spain) were chosen for the study, whose trade names are: Gris Alba, Grissal, Rosa Porriño and Rosavel (Figure 1). These are all healthy stones, with less than 5\% voids (cracks), although they differ in mineralogy, colour and grain size (Table 1). Previous studies (11) addressed the differences in water sorption with different surface finishes for some of these granites (Rosa Porriño and Rosavel).

Gris Alba is a grey, monzogranite with a medium even grain; it was the stone exhibiting the greatest cracking, with crack widths of around $8 \mu \mathrm{m}$. Grissal is likewise a grey monzogranite, in this case with a large uneven grain; it had the fewest and smallest cracks. Rosa

Tabla 1 / Table 1

Características generales de los granitos / Granite characteristics.

\begin{tabular}{|c|c|c|c|c|c|c|c|c|c|c|}
\hline \multirow{2}{*}{$\begin{array}{c}\text { Nombre } \\
\text { comercial / } \\
\text { Commercial } \\
\text { name }\end{array}$} & $\begin{array}{c}\text { Localización } \\
\text { Geográfica / } \\
\text { Location }\end{array}$ & \multicolumn{2}{|c|}{$\begin{array}{c}\text { Composición } \\
\text { mineralógica / } \\
\text { Mineralogical } \\
\text { composition (\%) }\end{array}$} & \multicolumn{4}{|c|}{ Color / Colour } & \multirow{2}{*}{$\begin{array}{c}\text { Tamaño de grano / } \\
\text { Grain size (mm) }\end{array}$} \\
\cline { 3 - 13 } & FK & P & Q & M & Visual / Visual & L* & a* & b* \\
\hline Gris Alba & $\begin{array}{c}\text { Cañiza } \\
\text { (Pontevedra) }\end{array}$ & 37 & 23 & 25 & 15 & $\begin{array}{c}\text { Gris claro / } \\
\text { Light grey }\end{array}$ & 67.0 & -1.7 & 4.1 & 5 \\
\hline Grissal & $\begin{array}{c}\text { Leiro } \\
\text { (Orense) }\end{array}$ & 35 & 32 & 25 & 8 & Gris / Grey & 61.3 & -2.9 & 2.3 & 12 \\
\hline Rosa Porriño & $\begin{array}{c}\text { Porriño } \\
\text { (Pontevedra) }\end{array}$ & 50 & 14 & 30 & 6 & Rosa / Pink & 62.4 & 3.3 & 11.2 & 12 \\
\hline
\end{tabular}

FK: Feldespato potásico / Alkali feldspar; P: Plagioclasa / Plagioclase; Q: Cuarzo / Quartz; M: Micas 


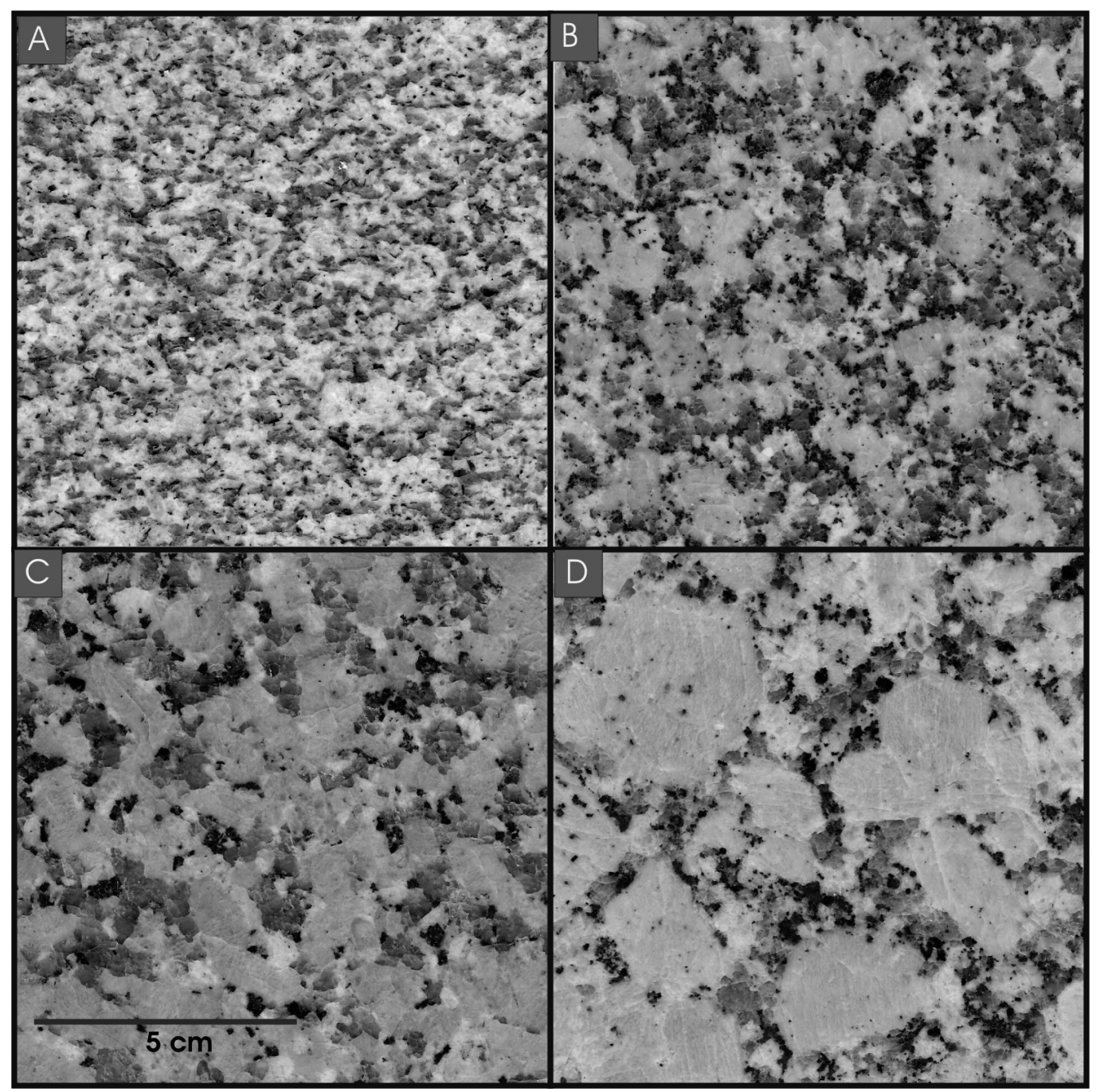

Figura 1. Granitos seleccionados. A) Gris Alba, B) Grissal, C) Rosa Porriño, D) Rosavel.

Figure 1. Granites studied. A) Gris Alba, B) Grissal, C) Rosa Porriño, D) Rosavel.

apertura de fisuras. Rosa Porriño es un sienogranito heterogranular, de grano grueso, que tiene feldespatos potásicos de color rosado con finas lamelas ferríferas rojas (12); su grado de fisuración es intermedio con microfisuras en torno a $6 \mu \mathrm{m}$. Rosavel es una cuarzosienita porfídica, con megacristales rosados (hasta $60 \mathrm{~mm}$ ) de feldespato potásico; su microfisuración es ligeramente superior y la apertura de fisuras es aproximadamente de $8 \mu \mathrm{m}$.

\section{PARTE EXPERIMENTAL}

De acuerdo con las propiedades medidas en cada caso se han preparado dos tipos de probetas de cada uno de los granitos: a) cubos de $5 \times 5 \times 5 \mathrm{~cm}$, y b) losetas de $10 \times 10 \times 2$ $\mathrm{cm}$ con una superficie pulida.

El ensayo de cristalización de sales se ha basado en la norma establecida para piedra natural (5), consistente en
Porriño, a syenogranite with a large even grain, contains pinkish potassium feldspars with thin red lamellae (12); it exhibits an intermediate degree of cracking, with widths on the order of $6 \mu \mathrm{m}$. Rosavel is a porphyritic quartz syenite with pink potassium feldspar megacrystals (up to 60 $\mathrm{mm})$; microcracking is slightly greater in this stone, with crack widths of approximately $8 \mu \mathrm{m}$.

\section{EXPERIMENTAL}

Two types of specimens of each granite were prepared: a) $5 \times 5 \times 5 \mathrm{~cm}$ cubes and b) $10 \times 10 \times 2 \mathrm{~cm}$ slabs with a polished surface.

The salt crystallization test, conducted to the existing standard for natural stone (5), consisted in submerging 
la realización de ciclos de inmersión de las probetas en una solución salina (sulfato sódico decahidratado al 14\%) durante cuatro horas y secado posterior. La temperatura de secado es un factor fundamental en la agresividad de la sal. La citada norma establece realizar el secado en un horno a $105^{\circ} \mathrm{C}$, aunque también tiene interés conocer el comportamiento cuando el secado tiene lugar a temperatura ambiente $\left(20-25^{\circ} \mathrm{C}\right)$. A elevadas temperaturas de secado se produce una rápida evaporación y las sales cristalizan en el interior de la roca, mientras que a temperatura ambiente la evaporación es más lenta, las sales pueden migrar y precipitar en superficie, dando lugar a eflorescencias.

El secado rápido se ha aplicado a las probetas cúbicas, ensayándose en este caso tres probetas de cada granito y en cada una de ellas se ha medido la pérdida de masa y la velocidad de propagación de ondas longitudinales (Vp). El secado lento se ha llevado a cabo en las losetas, y en su superficie pulida se ha medido la rugosidad y el color. En todos los casos las probetas se han sometido a 15 ciclos de cristalización de sales, midiéndose las propiedades seleccionadas como criterios de evaluación antes y después del ensayo, una vez eliminadas las sales de las probetas, tras lavados sucesivos.

La velocidad de ondas ( $\mathrm{Vp}$ ) se ha determinado con un equipo Pundit-Plus, a $1 \mathrm{MHz}$ de frecuencia. Las medidas se han realizado en las tres direcciones del espacio, obteniéndose el valor medio de cada probeta y, a su vez, el valor medio y la desviación típica de las tres probetas ensayadas de cada granito.

El análisis de la rugosidad superficial se ha realizado con un rugosímetro de contacto Mitutoyo Surftest SV2000N2, equipado con una punta de diamante de $2 \mu \mathrm{m}$, a la que se aplica una carga de $0,75 \mathrm{mN}$ para asegurar que no pierda contacto con la superficie y se desplace a velocidad constante. El rugosímetro está asociado a una mesa micrométrica, que permite medir el mismo perfil antes y después de los ensayos. Se han realizado 50 perfiles de $50 \mathrm{~mm}$ cada uno, la velocidad de medición ha sido $2 \mathrm{~mm} / \mathrm{s}$, el espaciamiento entre datos $10 \mu \mathrm{m}$ y la longitud de corte usada $25 \mathrm{~mm}$ (13). Los parámetros de rugosidad analizados han sido: Ra (desviación media aritmética del perfil) y Rz (máxima altura del perfil).

El color se ha medido con un colorímetro Minolta CR-200, equipado con una lámpara de xenon que produce un disparo de luz difusa de $8 \mathrm{~mm}$ de diámetro y utiliza un iluminante C (luz diurna media). El sistema de color usado fue CIE L*a*b*. En superficies heterocromáticas cada medida incluye diferentes colores, de acuerdo con el área de medición y el tamaño de grano de los minerales; en consecuencia, para la caracterización del color de rocas poliminerálicas como los granitos, el número de medidas the specimens in a saline solution (14\% decahydrated sodium sulphide) for four hours, after which they were dried. Drying temperature is decisive in salt aggressiveness. While the standard prescribes oven drying at $105^{\circ} \mathrm{C}$, determining stone performance when specimens are dried at ambient temperature $\left(20-25^{\circ} \mathrm{C}\right)$ is also useful. As evaporation takes place very rapidly at high drying temperatures, the salts crystallize inside the rock. At ambient temperatures the process is slower, however, allowing salts to migrate and precipitate on the surface, where they give rise to efflorescence.

Three cubic specimens of each granite were speed-dried and the weight loss and longitudinal wave propagation velocity $(V p)$ were measured in each. The slabs were subjected to slow drying and their surface was measured for roughness and colour. All specimens were subjected to 15 salt crystallization cycles. The properties selected as evaluation criteria were measured before and after the test, following on successive washing to eliminate the salt.

Wave velocity $(V p)$ was measured with a Pundit-Plus instrument at a frequency of $1 \mathrm{MHz}$. The measurements were taken in the three spatial directions to obtain a mean value for each specimen, along with the mean and standard deviation for the three specimens of each type of granite tested.

Surface roughness was measured with a Mitutoyo Surftest SV-2000N2 tester fitted with a $2 \mu \mathrm{m}$ diamond tip stylus, to which a load of $0.75 \mathrm{mN}$ was applied keep the speed constant and the tip in contact with the surface at all times. A micrometric table attached to the roughness tester ensured that the same profiles were taken before and after the tests. Fifty $50-\mathrm{mm}$ profiles were recorded at a measuring speed of $2 \mathrm{~mm} / \mathrm{s}$, with data spaced at 10 $\mu \mathrm{m}$ and a cutoff length of $25 \mathrm{~mm}$ (13). The roughness parameters analyzed were: Ra (mean profile deviation) and $R z$ (maximum profile height).

Colour was measured with a Minolta CR-200 colorimeter equipped with a pulse xenon lamp emitting an 8-mm diameter diffuse beam of illuminant $C$ (average daylight) light. The standard CIE L*a*b* colour system was used. Each measurement of multi-coloured surfaces includes different colours, subject to the area measured and mineral grain size; consequently, in the colour characterization of polimineral rocks such as granite, the number of measurements depends on the grain size (14). In Rosavel, 
depende del tamaño de grano (14). Rosavel, que es la roca de mayor tamaño de grano, precisa 200 medidas para alcanzar parámetros del color estables. En el resto de los granitos se ha tomado ese mismo número de medidas.

\section{RESULTADOS}

Finalizados los 15 ciclos de cristalización de sales se ha observado el aspecto de la superficie de las probetas, y se han determinado las propiedades utilizadas para evaluar los daños. Dichas medidas post-ensayo se han realizando en las mismas condiciones en las que se obtuvieron los valores iniciales. Hay que resaltar que cuando se observan a simple vista las distintas probetas apenas se aprecian cambios.

Variación de masa. A lo largo de los ciclos todos los granitos experimentan ligeras pérdidas de masa cuando se sumergen en la solución salina. El material desprendido es mayoritariamente de naturaleza biotítica. En la Tabla 2 se expresa el resultado de la pérdida de masa en porcentaje y en $\mathrm{g} / \mathrm{m}^{2}$. En los granitos Gris Alba y Grissal no llegan a detectarse variaciones de masa, y en Rosavel y Rosa Porriño las pérdidas son muy pequeñas (inferiores al 0,04\%). Estas pequeñas diferencias de comportamiento se atribuyen a que los granitos Gris Alba y Grissal presentan las biotitas dispersas en la roca y apenas se ven afectadas por el ensayo, lo que explica que no se detecten variaciones de masa. En Rosa Porriño y Rosavel las biotitas se encuentran formando agregados y se observa que el daño en esas zonas es mayor y también lo es la pérdida de masa. the rock with the largest grain size, 200 measurements had to be taken before stable colour parameters were recorded. The same number of measurements was taken in all the other granites.

\section{RESULTS}

After 15 salt crystallization cycles, the specimen surface was inspected for changes in appearance and the values of the properties used to evaluate the damage were found under the same conditions as the pre-test measurements. The changes in the specimens were barely visible to the naked eye.

Variation in mass. A slight weight loss was recorded for all the granites when submerged in the saline solution. The material released was primarily biotitic. Weight loss is given in Table 2 in percentage and $\mathrm{g} / \mathrm{m}^{2}$. No weight loss was detected in Gris Alba or Grissal and the loss observed in Rosavel and Rosa Porriño was very small (under $0.04 \%$ ). These slight differences in behaviour were attributed to the fact that biotite in Gris Alba and Grissal is scattered throughout the rock and barely affected by the test, which would explain why no variations in mass were detected. The biotite clusters observed in Rosa Porriño and Rosavel underwent greater damage: hence the weight loss.

Tabla 2 / Table 2

Variación de masa / Variation in mass.

\begin{tabular}{|c|c|c|}
\hline Granito / Granite & $\Delta \mathbf{M}(\mathbf{\%})$ & $\Delta \mathbf{M} / \mathbf{S}\left(\mathbf{g} / \mathbf{m}^{\mathbf{2}}\right)$ \\
\hline Gris Alba & $-0.003 \pm 0.005$ & $-0.6 \pm 0.1$ \\
\hline Grissal & $-0.006 \pm 0.005$ & $-1.2 \pm 0.1$ \\
\hline Rosa Porriño & $-0.036 \pm 0.008$ & $-7.8 \pm 1.7$ \\
\hline Rosavel & $-0.018 \pm 0.016$ & $-3.8 \pm 3.5$ \\
\hline
\end{tabular}

Valor medio y desviación típica / Average and standard deviation.

Velocidad de propagación de ondas. En la Tabla 3 se indican los valores de Vp antes y después del ensayo, así como su variación en porcentaje respecto al valor inicial. Se observa que todos los granitos presentan reducción en la velocidad tras el ensayo, lo que se atribuye a la apertura o creación de fisuras. Gris Alba, que es el granito inicialmente más fisurado y con mayor apertura de fisuras es el que menor disminución presenta (1\%). Grissal y Rosa Porriño, que son los menos fisurados y de menor
Wave propagation velocity. Table 3 gives the $V p$ values before and after the test, as well as the percentage of variation. All the granites showed a reduction in velocity after the test, which was attributed to the widening of existing cracks or the appearance of new cracks. Gris Alba, which was the granite with the greatest initial cracking and widest cracks, exhibited the lowest decline (1\%). The decline in Vp (14\%) was steepest in Grissal and Rosa Porriño, which had the fewest and narrowest cracks. 
apertura de fisuras, muestran mayor disminución en Vp (14\%). Rosavel tiene una fisuración y un comportamiento intermedio. De acuerdo con estos resultados, los granitos que presentan menor fisuración y menor apertura de fisuras son más susceptibles a que se incremente dicha fisuración y quede dañada la roca en su interior. Este hecho puede ser debido a la mayor presión ejercida al cristalizar la sal en espacios más reducidos $(15,16)$.
Rosavel, with intermediate cracking, exhibited intermediate behaviour. According to these results, the least cracked granites are the one most liable to increases in cracking and crack widths, with the concomitant damage to rock interiors. This may be due to the greater pressure exerted when salt crystallizes in smaller spaces $(15,16)$.

Tabla 3 / Table 3

Velocidad de propagación de ondas longitudinales / Wave propagation velocity.

\begin{tabular}{|c|c|c|c|}
\hline \multirow{2}{*}{ Granito / Granite } & \multicolumn{2}{|c|}{ Vp (m/s) } & \multirow{2}{*}{$\Delta \mathbf{v p ~ ( \% )}$} \\
\cline { 2 - 4 } & $\mathbf{0 ~ C}$ & $\mathbf{1 5} \mathbf{C}$ & -1 \\
\hline Gris Alba & $4182 \pm 30$ & $4143 \pm 27$ & -14 \\
\hline Grissal & $5338 \pm 33$ & $4612 \pm 28$ & -13 \\
\hline Rosa Porriño & $5025 \pm 54$ & $4352 \pm 40$ & -8 \\
\hline Rosavel & $4853 \pm 55$ & $4455 \pm 180$ & \\
\hline
\end{tabular}

Valor medio y desviación típica / Average and standard deviation.

(0 C): 0 ciclos / cycles; (15 C): 15 ciclos / cycles.

Rugosidad. En la Tabla 4 se recogen los valores de los parámetros Ra y Rz antes y después del ensayo, así como su variación en porcentaje. En general se produce un aumento de rugosidad con los ciclos, siendo Grissal la roca que presenta mayor variación (alrededor de $50 \%$ en Ra y $200 \%$ en Rz) seguida de Gris Alba ( $50 \%$ en Ra y $100 \%$ en Rz), mientras que en Rosa Porriño y Rosavel las variaciones son menores (inapreciables en Ra y del $50 \%$ en Rz). El aumento de rugosidad se atribuye al levantamiento de las biotitas y a la alteración de las plagioclasas durante la cristalización de sales, afectando sobre todo a los picos del perfil (Rz), mientras que el feldespato potásico apenas sufre cambios (Figura 2). Estos hechos justifican que los granitos con mayor proporción de feldespato potásico (Rosa Porriño y Rosavel) muestran menores variaciones de rugosidad que los granitos con más plagioclasa y mica (Gris Alba y Grissal).
Roughness. Table 4 shows the values of parameters $R a$ and $R z$ before and after the test and their percentage variation. Roughness increased after the cycles as a general rule, most notably in Grissal (Ra by around 50\% and $R z$ by around 200\%); the variations in Rosa Porriño and Rosavel were smaller (negligible for Ra and 50\% for $R z$ ). This increased roughness was attributed to the biotite protrusions and plagioclase alteration induced by salt crystallization, which were detected primarily as differences in profile peaks (Rz). The potassium feldspar was barely impacted (Figure 2). These findings explain why the granites with a higher potassium feldspar content (Rosa Porriño and Rosavel) exhibited smaller variations in roughness than granites with higher proportions of plagioclase and mica (Gris Alba and Grissal).

Tabla 4 / Table 4

Variación en los parámetros de rugosidad: Ra (desviación media aritmética del perfil), Rz (máxima altura del perfil). Variation in roughness parameters: $R a$ (arithmetical mean deviation of the profile), $R z$ (maximum height of the profile).

\begin{tabular}{|c|c|c|c|c|c|c|}
\hline \multirow{2}{*}{ Granito / Granite } & \multicolumn{2}{|c|}{$\mathbf{R a}(\boldsymbol{\mu m})$} & \multirow{2}{*}{$\boldsymbol{R} \mathbf{R}(\mathbf{\%})$} & \multicolumn{2}{|c|}{$\mathbf{R z}(\boldsymbol{\mu m})$} & \multirow{2}{*}{$\boldsymbol{\Delta} \mathbf{R z}(\%)$} \\
\cline { 2 - 3 } \cline { 5 - 6 } & $\mathbf{0 ~ C}$ & $\mathbf{1 5} \mathbf{C}$ & & $\mathbf{0 ~ C}$ & $\mathbf{1 5} \mathbf{C}$ & \\
\hline Gris Alba & 1.036 & 1.549 & 50 & 30.7 & 60.2 & 96 \\
\hline Grissal & 0.635 & 1.039 & 63 & 15.5 & 44.9 & 189 \\
\hline Rosa Porriño & 1.145 & 1.199 & 5 & 37.5 & 55.7 & 49 \\
\hline Rosavel & 1.058 & 1.007 & -5 & 35.3 & 53.3 & 51 \\
\hline
\end{tabular}

(0 C): 0 ciclos / cycles; (15 C): 15 ciclos / cycles. 


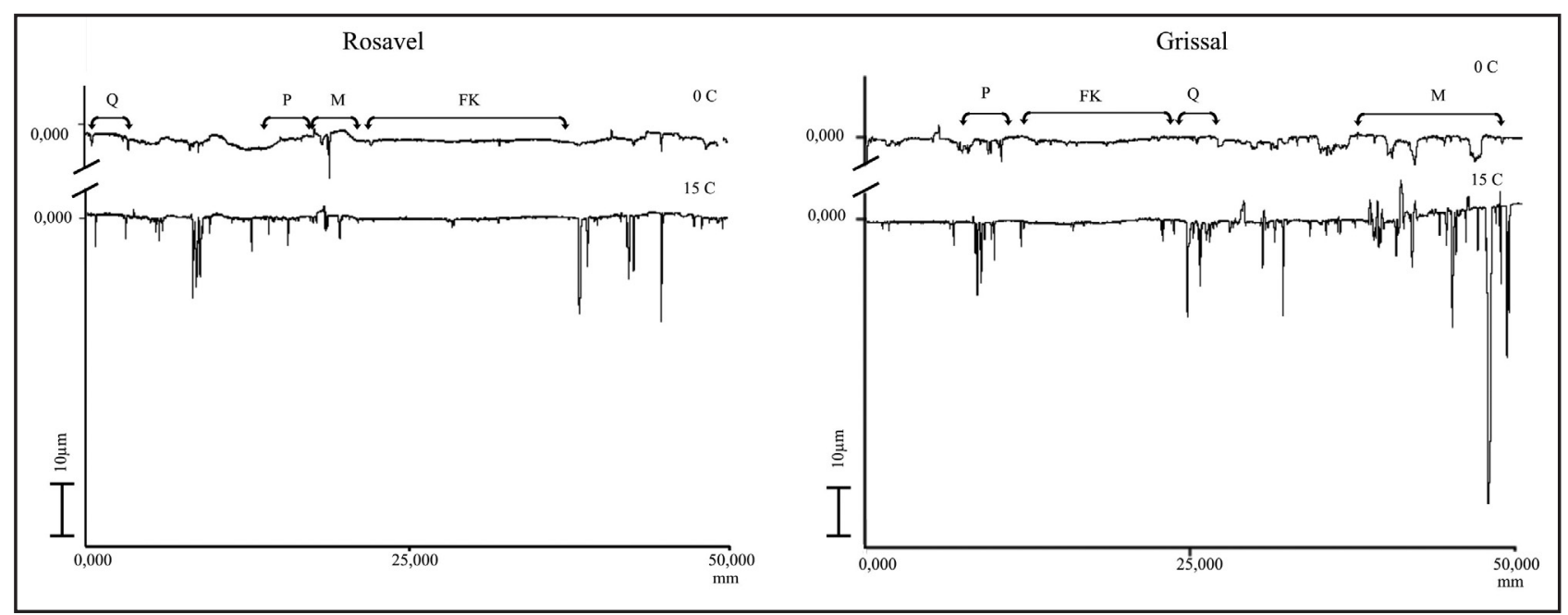

Figura 2. Perfiles de rugosidad tomados en las mismas coordenadas antes $(0 \mathrm{C})$ y después de 15 ciclos $(15 \mathrm{C})$ de cristalización de sales en los granitos Rosavel y Grissal. Se observa que la rugosidad no varía en el feldespato potásico (FK), cambia ligeramente en el cuarzo (Q) y en la plagioclasa (P), y experimenta notable variación en las micas (M). Estos cambios se atribuyen a la apertura de fisuras en el cuarzo y pequeñas pérdidas de material en la plagioclasa, y sobre todo a la apertura de los planos de exfoliación y al posterior levantamiento de las láminas de mica.

Figure 2. Roughness profiles were measured at the same point in Rosavel and Grissal granite before ( $0 \mathrm{C})$ and after 15 salt crystallization cycles (15 C). Roughness undergoes no change in potassium feldspar (FK), a slight change in quartz (Q) and in plagioclase (P), and substantial variation in mica (M). These changes are attributed to the appearance of fissures in quartz, minor spalling in plagioclase and widening of mica cleavage planes and subsequent detachment of the mineral.

Color. En la Tabla 5 y en la Figura 3 se muestran las variaciones de color tras el ensayo. En general, el cambio afecta en mayor o menor grado a todos los parámetros cromáticos. En los cuatro granitos se producen ligeras pérdidas de luminosidad $\left(L^{*}\right)$, siendo éstas más notables en Rosa Porriño. Los parámetros $a^{*}$ y b* sufren menor variación, excepto en Rosavel. En los granitos rosas estos
Colour. Table 5 and Figure 3 show the variations in colour after the test. Generally speaking, all the chromatic parameters underwent some degree of change. Although some slight brightness ( $\left.L^{*}\right)$ loss was recorded in the four granites, rosa porriño was the stone most deeply impacted. Variations were smaller in parameters $a^{*}$ and $b^{*}$, except in rosavel. In pink granite these changes tended to

Tabla 5 / Table 5

Variación de color. / Variation in colour.

\begin{tabular}{|c|c|c|c|c|c|}
\hline Granito / Granite & $\mathbf{\Delta} \boldsymbol{*}$ & $\mathbf{\Delta} \mathbf{*} *$ & $\mathbf{\Delta b}$ & $\Delta \mathbf{C} *$ & $\Delta \mathbf{h}^{*}$ \\
\hline Gris Alba & -0.74 & -0.05 & -0.07 & -0.05 & -1.05 \\
\hline Grissal & -0.98 & -0.01 & 0.03 & 0.03 & 0.29 \\
\hline Rosa Porriño & -1.36 & 0.05 & 0.20 & 0.21 & 0.06 \\
\hline Rosavel & -0.83 & 0.24 & 0.46 & 0.40 & 3.34 \\
\hline
\end{tabular}

Croma / Chroma: $\mathrm{C}=\left(\mathrm{a}^{2}+\mathrm{b}^{* 2}\right)^{1 / 2}$. Tono / Hue: $\mathrm{h}=\operatorname{arctg}\left(\mathrm{b}^{*} / \mathrm{a}^{*}\right)$.

cambios tienden a intensificar el color ( $\Delta C^{*}$ positivo) y a virar hacia tonos amarillo-rojizos, lo cual puede deberse a cambios en el estado de oxidación del hierro como en otros procesos (17). En este caso los cambios no parecen significativos para el número de ciclos realizados, pero indican una tendencia que puede verse acentuada al incrementarse dicho número. intensify the colour (positive $\Delta C^{*}$ ), which turned reddish yellow, due perhaps to changes in the state of iron oxidation, as described for other processes (17). Although the changes did not appear to be significant in 15 cycles, they were indicative of a trend that might intensify if the number were increased. 


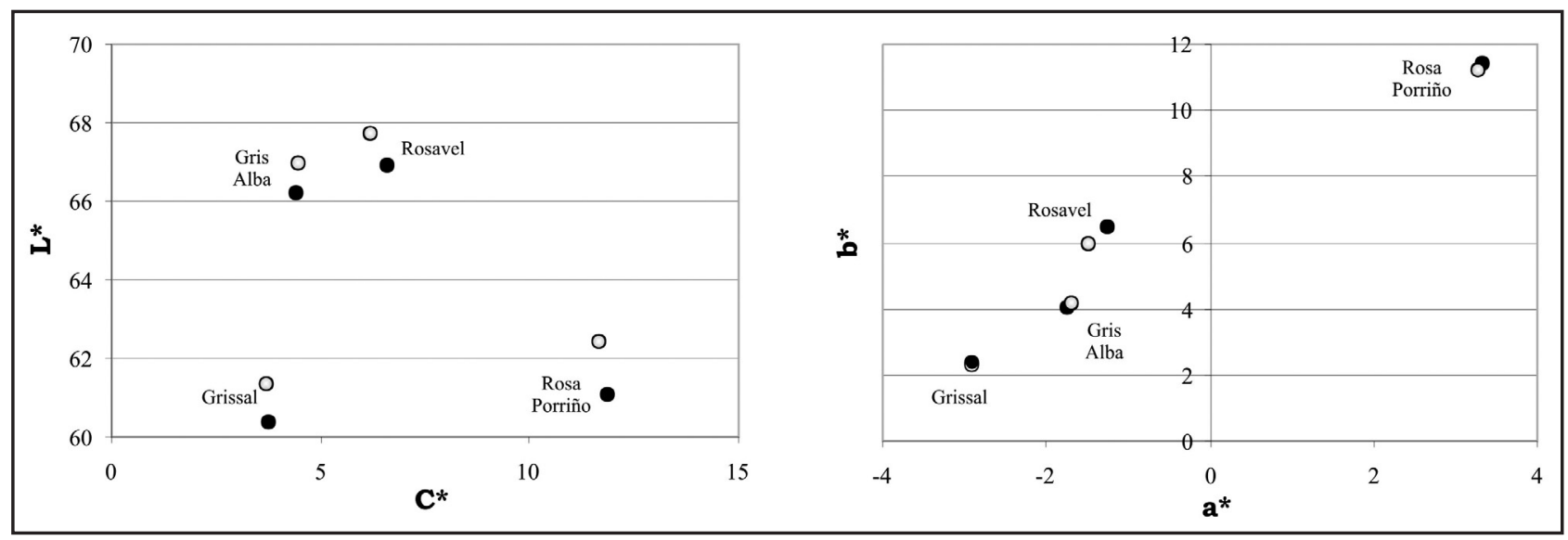

Figura 3. Representación gráfica de los parámetros de color antes (círculo gris) y después de 15 ciclos (círculo negro) de cristalización de sales. Se observa pérdida de luminosidad en todos los granitos y variaciones poco significativas en el cromático, excepto en Rosavel. Figure 3. Colour parameters before (grey circle) and after 15 salt crystallization cycles (black circle). Brightness is observed to decline in all the granites and, with scantly significant variations in chromaticity, except in Rosavel.

\section{CONCLUSIONES}

La norma establecida para valorar la resistencia de la piedra natural a la cristalización de sales puede ser válida en rocas cristalinas de baja porosidad, siempre que vaya acompañada de otros parámetros para valorar los daños, tales como la velocidad de propagación de ondas longitudinales. Se comprueba que a medida que avanzan los ciclos, si se generan nuevas fisuras o aumenta la apertura de las ya existentes, disminuye dicha velocidad.

Este tipo de rocas ornamentales con frecuencia presentan superficies pulidas y los cambios en dichas superficies pueden valorarse mediante parámetros como la rugosidad o el color. La rugosidad superficial aumenta con los ciclos y está provocada esencialmente por la apertura de los planos de exfoliación de las micas. En cuanto al color se produce una pérdida de luminosidad y las variaciones cromáticas se atribuyen a cambios en el estado del hierro de los minerales. Todas estas propiedades proporcionan datos cuantitativos para conocer el inicio de daños inducidos por la sal, ya sea en el seno de la roca o en su superficie.

Comparando el comportamiento de dichas propiedades antes y después del ensayo de cristalización de sales en los cuatro granitos (Figura 4), se observa que las disminuciones en la velocidad de propagación de ondas son más significativas que las pérdidas de peso, y que en superficies pulidas son significativas las diferencias de rugosidad y posiblemente las de color. En los granitos de grano grueso y baja porosidad la red fractográfica se ve más afectada por el ensayo; los más ricos en micas y plagioclasas pierden con más facilidad el pulimento y los de color rosa sufren mayores variaciones cromáticas.

\section{CONCLUSIONS}

The existing standard for evaluating natural stone resistance to salt crystallization may be valid in low porosity crystalline rocks if supplementary parameters for assessing damage, such as longitudinal wave propagation velocity, are measured. When new cracks appeared or existing cracks widened during the cycles, velocity was observed to decline.

This sort of ornamental stone frequently has polished surfaces where parameters such as roughness or colour can be measured. Surface roughness increased after the crystallization cycles essentially as a result of the widening of mica cleavage planes. All three colour parameters were affected, with brightness declining slightly and variations in chromaticity attributed to the state of the iron ion in the minerals. The quantitative data gathered on these properties help to detect the beginning of saltinduced damage, whether inside the stone or on the surface.

A comparison of these properties in the four granites before and after the salt crystallization test (Figure 4) showed that the decline in wave propagation velocity was more significant than weight loss, and the differences in roughness and possibly colour were significant in polished surfaces. The crack network was impacted more intensely in coarse grain, low porosity granite, the polish wore more readily off stone with a high mica and plagioclase content, and the pink rocks underwent greatest chromatic change. 


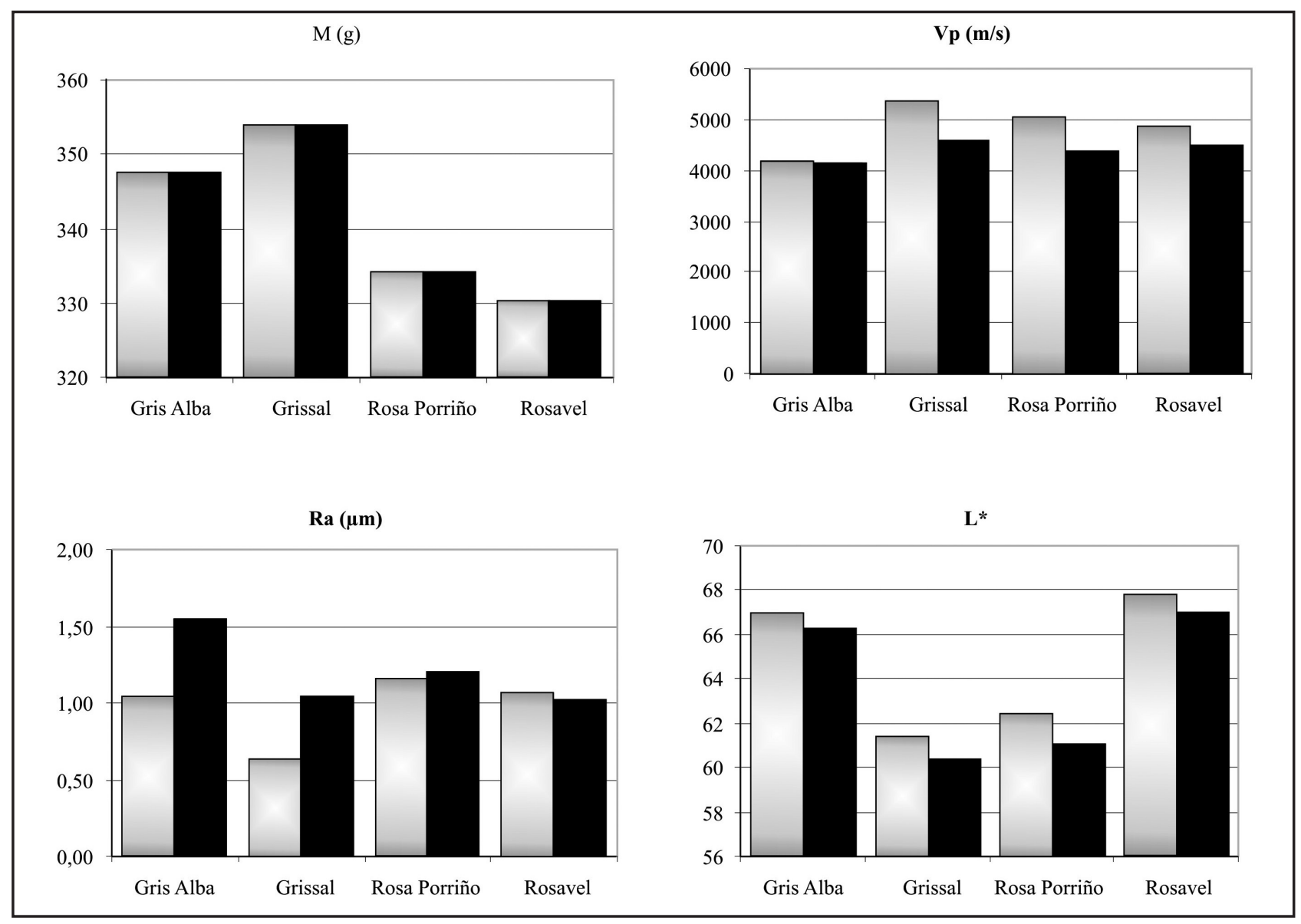

Figura 4. Variaciones experimentadas en las propiedades medidas antes (barra gris) y después de 15 ciclos (barra negra) de cristalización de sales: masa $(M)$, velocidad de propagación de ondas (Vp), desviación media del perfil de rugosidad (Ra) y luminosidad ( $\left.L^{*}\right)$.

Figure 4. Variations in granite properties measured before (grey bar) and after 15 salt crystallization cycles (black bar): mass (M), wave propagation velocity $(V p)$, mean deviation of the roughness profile $(R a)$ and brightness $\left(L^{*}\right)$.

En definitiva, y a la vista del estudio realizado, puede afirmarse que, aunque la degradación de un granito ornamental es un proceso a largo plazo, las sales solubles pueden inducir a corto o medio plazo daños que afectan a sus características estéticas e inciden de forma significativa en su durabilidad.

\section{AGRADECIMIENTOS}

A la Comisión de Ciencia y Tecnología (CICYT), por el proyecto: MAT2004-06804-C02-01. "Durabilidad de rocas ornamentales cristalinas utilizadas en revestimientos exteriores: Criterios de calidad y sugerencias de uso". A la "Asociación de Canteiras de Galicia", y en especial a su gerente D. José María González Araujo, por facilitarnos las probetas de los granitos.
In short, in light of the above findings, although ornamental granite decay is a long-term process, soluble salts may induce short- or medium-term damage that affects its aesthetic qualities and significantly impact its durability.

\section{ACKNOWLEDGEMENTS}

This research was funded by the Spanish Science and Technology Commission under project MAT2004-06804C02-01, "Durabilidad de rocas ornamentales cristalinas utilizadas en revestimientos exteriores: Criterios de calidad y sugerencias de uso". The authors wish to thank the Asociación de Canteiras de Galicia and in particular its manager José María González Araujo for providing the granite specimens. 


\section{BIBLIOGRAFÍA / BIBLIOGRAPHY}

(1) Flatt, R. J.: "Salt damage in porous material: how high supersaturations are generated". Journal of Crystal Growth 242 (2002) pp. 435-454.

(2) Tsui, N., Flatt, R. J. and Scherer, G. W.: "Crystallization damage by sodium sulphate". Journal of Cultural Heritage 4 (2003) pp. $109-115$.

(3) Rodriguez-Navarro, C. and Doehne, E.: "Influence of evaporation rate supersaturation and crystallization pattern". Earth Surf. Proccess. Landforms 24 (1999) pp. 191-209.

(4) Moreno, F., Vilela, S. A. G., Antunes, A. S. G. and Alves, C. A. S.: "Capillary-rising salt pollution and granitic stone erosive decay in the parish church of Torre de Moncorvo". (NE Portugal)-implications for conservation strategy". Journal of Cultural Heritage 7 (2006) 56-66.

(5) UNE-EN 12370:1999. "Métodos de ensayo para piedra natural. Determinación de la resistencia a la cristalización de sales". AENOR (1999) p. 10.

(6) Cardell, C., Rivas, T., Mosquera, M. J., Birginie, J. M., Moropoulou, A., Prieto, B., Silva, B., y Van Grieten, R.: "Patterns of damage in igneous and sedimentary rocks Ander conditions simulating sea-salt weathering". Earth Surf. Process. Landforms 28 (2003) pp. 1-14.

(7) Grossi, C. M. y Esbert, R. M.: "Las sales solubles en el deterioro de rocas monumentales: revisión bibliográfica". Mater. Construcc. 44, no 235 (1993) pp. 15-30.

(8) Sousa, L. M. O., Calleja, L., Suárez del Río, L. M. and Rodríguez Rey, A.: "Anisotropy of propagación of the seismic waves in granites". $8^{\circ}$ Congreso Nacional de Geotecnia, Lisboa (2002) pp. 507-516.

(9) Valdeón, L., Montoto, M., Calleja, L. and Esbert, R. M.: "A method to assess spatial coordinates in the art and archaeological objects: application of tomography to a dolmen". Journal of Archaeological Science 24 (1997) pp. 337-346.

(10) Benavente, D., Martínez Verdú, F., Bernabeu, A., Viqueira, V., Fort, R., García del Cura, M.A., Illueca, C. and Ordóñez, S.: "Influence of surface roughness on color changes in building stones". Color Research and Application 28, no 5 (2003) pp. 343-351.

(11) Rojo, A., Alonso, F. J. and Esbert, R. M.: "Hydric properties of some iberian ornamental granites whit h different superficial finishes: a petrophysical interpretation". Mater. Construcc. 53, n० 269 (2003) pp. 61-72.

(12) Vergara, A.: "Contribución al estudio del color del granito Rosa Porriño". Boletín Geológico y Minero 104, no 1 (1993) pp. 65-71.

(13) Alonso, F. J., Vázquez, P., Esbert, R. M. and Ordaz, J.: "Influence of measuring conditions on roughness parameters of ornamental rocks". Preservation of Natural Stone and Rock Weathering, Proceeding of workshop, Madrid (Ed.: Taylor\& Francis) (2007) pp. 13-16.

(14) Costa, D., Delgado Rodrigues, J.: "Assessment of colour changes due to treatment products in heterocromatic stones". Degradation and Conservation of Granitic rocks in Monuments, Proceeding of EC workshop, Santiago de Compostela (1996) pp. 325-330.

(15) Benavente, D., García del Cura, M. A., García-Guinea, J., Sánchez-Moral, S. and Ordoñez, S.: "Role of pore structure in salt crystallisation in unsatured porous stone". Journal of Crystal Growth 260 (2004) pp. 532-544.

(16) Rodriguez-Navarro, C., Doehne, E., Sebastian, E.: "How does sodium sulphate crystallize? Implications for the decay and testing building materials". Cement and concrete research 30 (2000) pp. 1.527-1.534.

(17) Grossi, C. M., Alonso, F. J., Esbert, R. M. and Rojo, A.: "Effect of laser cleaning on granite color changes". Color Research and Application 32, no 2 (2007) pp. 152-159. 